\title{
PROMOÇÃO DO CRESCIMENTO E ENRAIZAMENTO DE MINIESTACAS DE Eucalyptus dunnii POR RIZOBACTÉRIAS E BACTÉRIAS DO FILOPLANO
}

\author{
Ana Claudia Spassin ${ }^{1}$, Paula Burigo Vandresen ${ }^{1}$, Dyanndra Neves ${ }^{1}$, Flávio Augusto de Oliveira Garcia ${ }^{2 *}$, \\ Daniele Ukan ${ }^{2}$, Fabiana Schmidt Bandeira Peres ${ }^{2}$ \\ ${ }^{1}$ Universidade Estadual do Centro-Oeste, Programa de Pós-graduação em Ciências Florestais, Irati, Paraná, Brasil - \\ anaspassin@yahoo.com.br; paulabph@hotmail.com; florestal.dyanndra@yahoo.com.br \\ ${ }^{2}$ Universidade Estadual do Centro-Oeste, Departamento de Engenharia Florestal, Irati, Paraná, Brasil - fgarcia.unicentro@ gmail.com*; \\ daniukan@yahoo.com.br; fsbandeira@hotmail.com
}

Recebido para publicação: 17/11/2014 - Aceito para publicação: 12/04/2016

\begin{abstract}
Resumo
$\mathrm{O}$ uso de microrganismos com efeito de promotores de crescimento e enraizamento de plantas tem apresentando resultados promissores no desenvolvimento de mudas clonais. Assim, o objetivo do estudo foi avaliar o potencial de isolados de rizobactérias e residentes do filoplano na promoção de crescimento e enraizamento de miniestacas de Eucalyptus dunnii. O experimento foi conduzido no delineamento de blocos casualizados, em arranjo fatorial $4 \times 4 \times 3$, sendo os fatores constituídos por quatro coletas, quatro isolados bacterianos e três métodos de aplicação. Foram avaliados o percentual de sobrevivência das miniestacas na saída da casa de vegetação, casa de sombra e área de pleno sol, e o enraizamento das miniestacas aos 90 dias de idade. A resposta na sobrevivência de mudas na casa de vegetação, sombra e área de pleno sol variaram de acordo com o isolado, forma de aplicação e período de realização da coleta. Não foi observado efeito significativo dos isolados bacterianos sobre o enraizamento das miniestacas. Os isolados bacterianos apresentaram ora efeito benéfico, ora ausência de efeito para a sobrevivência e enraizamento das miniestacas. Por ser o primeiro relato do uso de rizobactérias e residentes de filoplano na promoção de crescimento de $E$. dunnii, há necessidade de novos estudos para a confirmação da efetividade desses microrganismos.

Palavras-chave: Miniestaquia; propagação vegetativa; produção de mudas.
\end{abstract}

\section{Abstract}

Growth promoting and rooting of Eucalyptus dunnii for rhizobacteria and epiphytic bacteria. The use of microorganisms with plant growth promoting and rooting effect they have results promising for production of clonal seedlings of Eucalyptus. Thus, the aim of this study was evaluate rhizobacteria and epiphytic bacterial potential in the growth promoting and rooting of minicutting of Eucalyptus dunnii. The assay were conducted in randomized block design in a factorial $4 \times 3 \times 3$, being factors period to harvesting of shoots, four bacterial isolates and three methods of bacterial application. Percent survival of minicuttings was assessed in the end of greenhouse phase, in the end of shadow house phase and in the end of acclimation sun area phase, the minicutting rooting was evaluate after 90 days of staking of minicuttings. Thereply in the survival in the green house, shadow house and the acclimation sun area has varied according with bacterial isolates, method of applied and period assay realized. Do not observed significant effect of the isolates under rooting of the minicuttings. Based on the results concluded that bacterial isolates sometimes has beneficial effect, sometimes has nothing effect under survival and rooting of minicutting of E. dunnii. How is the first relate of the use to rhizobacteria and epiphytic bacterias as E. dunnii growth promoter and rooting, more studies are needed for confirmation of effective these microorganisms.

Keywords: Minicutting; vegetative propagation; seedling production.

\section{INTRODUÇÃO}

A produção de mudas é um dos fatores que influenciam o cultivo de espécies florestais, inclusive podendo impedir o plantio de determinado material, quando não há êxito na sua propagação.

Eucalyptus dunnii Maiden é uma espécie que apresenta problemas para a produção de mudas, pela baixa produção de sementes. Outro fator é a dificuldade de enraizamento quando propagada por miniestaquia, que, segundo Assis e Mafia (2007), é uma característica de espécies subtropicais do gênero Eucalyptus, tais como E. dunnii, E. viminalis e E. benthamii.

Devido ao interesse na propagação clonal de E. dunnii sobretudo pela possibilidade do cultivo dessa espécie em regiões com ocorrência frequente de geadas no inverno, algumas práticas têm sido adotadas, como produção de híbridos com outras espécies de Eucalyptus, bem como variações na época de coleta e das brotações no estádio fisiológico da estaca (BRONDANI et al., 2010a) e uso de reguladores de crescimento para aumento

FLORESTA, Curitiba, PR, v. 46, n. 3, p. 387 - 395, jul. / set. 2016

Spassin, A. C. et al.

ISSN eletrônico 1982-4688

DOI: $10.5380 /$ rf.v46i3.38586 
do percentual de enraizamento das miniestacas (BRONDANI et al., 2010b). Contudo a produção de mudas de E. dunnii em viveiros florestais ainda apresenta níveis insuficientes para atender a demanda de área de cultivo com a espécie.

O uso de microrganismos promotores do crescimento de plantas é adotado como prática rotineira na agricultura mundial. É fato que a produção de leguminosas como feijão e soja são dependentes da associação de bactérias com esses vegetais. Na área florestal, essa prática não é muito disseminada, embora existam relatos de sucesso na produção clonal de híbridos de E. urophylla x E. grandis (TEIXEIRA et al., 2007). Normalmente tem-se utilizado rizobactérias promotoras do crescimento de plantas, mais conhecidas como PGPR (Plant Growth-Promoting Rhizobacteria), sobretudo quando se realiza a prospecção do seu efeito no enraizamento de estacas florestais (MAFIA et al., 2009; PERALTA et al., 2012; RAASCH et al., 2013).

Contudo existem ainda dúvidas sobre a eficácia desses microrganismos, formas de aplicação e amplitude do efeito promotor, dentre outras. Nesse sentido, o objetivo deste trabalho foi avaliar o potencial de isolados de rizobactérias e bactérias residentes de filoplano sob três formas de aplicação como promotores de enraizamento de miniestacas de E. dunnii.

\section{MATERIAL E MÉTODOS}

O presente trabalho foi realizado no Laboratório de Patologia Florestal (LPF) e no Viveiro de Pesquisas do Departamento de Engenharia Florestal da Universidade Estadual do Centro-Oeste (UNICENTRO), Campus de Irati (PR). Situa-se na região centro-sul do estado, a $153 \mathrm{~km}$ de Curitiba, com altitude de 812 metros. O clima da região é do tipo $\mathrm{Cfb}$, segundo a classificação de Köppen-Geiger. A precipitação média mensal é de $193,97 \mathrm{~mm}$, com temperatura média anual de $24,2{ }^{\circ} \mathrm{C}$ no verão e de $11^{\circ} \mathrm{C}$ no inverno, com umidade relativa média anual de $79,58 \%$.

\section{Cultivo e preparo da suspensão de propágulos de microrganismos}

Foram utilizados três isolados bacterianos obtidos de filoplano de E. benthamii e um isolado de rizobactéria obtido a partir de solo rizosférico de plantas de E. Benthamii, todos pertencentes à coleção do LPF, tendo os seguintes códigos: RFE05, RFE32, RFE42 e UBK12. As bactérias estavam preservadas em óleo mineral e foram repicadas para placas de Petri contendo meio TSA ${ }^{\circledR}$ (trypticase soy agar) esterilizado. Foram incubadas em BOD por 24 horas a $28^{\circ} \mathrm{C}$ no escuro. $\mathrm{O}$ crescimento bacteriano formado na superfície do meio foi suspendido em solução salina $[\mathrm{NaCl} 0,85 \%(\mathrm{p} / \mathrm{v})]$ com concentração ajustada para $1 \times 10^{8}$ U.F.C. $\times \mathrm{mL}^{-1}$. As suspensões de células bacterianas obtidas foram utilizadas para a aplicação nas miniestacas de E. dunnii de acordo com cada tratamento realizado.

\section{Coleta das brotações e preparo das miniestacas}

As brotações foram coletadas de minicepas produzidas em minijardim clonal, cultivadas em vasos plásticos com dimensões de $34 \mathrm{~cm}$ de altura x $33 \mathrm{~cm}$ de largura x $80 \mathrm{~cm}$ de comprimento, no espaçamento de $10 \times 10 \mathrm{~cm}$, em substrato de areia. As minicepas foram formadas de mudas de E. dunnii produzidas a partir de sementes obtidas em pomares de polinização controlada, cedidas pela empresa Klabin S. A. No total, 24 mudas com 120 dias de idade foram transplantadas para vasos plásticos para o início da formação do minijardim clonal.

A fertilização utilizada no minijardim foi à base de NPK (4-14-8), nas concentrações de 0,5 g.planta ${ }^{-1}$, realizada uma vez por semana durante a formação das minicepas e duas vezes por semana após o estabelecimento do minijardim clonal. Juntamente com o NPK, realizou-se a aplicação de micronutrientes a um volume de $10 \mathrm{ml}$ por vaso plástico. A solução nutritiva foi preparada segundo Alfenas et al. (2009), sendo composta por sulfato de manganês $\left(1,3 \mathrm{mg} . \mathrm{L}^{-1}\right)$, ácido bórico $\left(2,4 \mathrm{mg} . \mathrm{L}^{-1}\right)$, cloreto de zinco $\left(0,4 \mathrm{mg} \cdot \mathrm{L}^{-1}\right)$, sulfato de cobre $\left(0,34 \mathrm{mg} . \mathrm{L}^{-1}\right)$, molibdato de amônia $\left(0,07 \mathrm{mg} . \mathrm{L}^{-1}\right)$, sulfato ferroso $\left(2,16 \mathrm{mg} . \mathrm{L}^{-1}\right)$ e EDTA dissódico $\left(3,3 \mathrm{mg} . \mathrm{L}^{-1}\right)$.

O minijardim utilizado para a coleta das brotações foi alocado em uma área com cobertura plástica, para evitar incidência direta de água de chuva sobre as minicepas. No início das coletas, o minijardim possuía 09 meses de implantação.

Foram realizadas coletas nos meses de maio, julho, outubro e novembro de 2013, uma em cada mês. Cada período de coleta foi considerado como um fator, devido a mudanças ocorridas nas variáveis ambientais, sobretudo umidade, temperatura e luz às quais as minicepas foram expostas.

As brotações foram coletadas de forma seletiva e contínua, de maneira a manter as minicepas em bom estado vegetativo e com sistema radicular ativo. No período em que as brotações não foram coletadas, realizaram-se podas de manutenção a cada 15 a 20 dias, a fim de manter a sanidade e produtividade do minijardim clonal.

As coletas de brotações foram realizadas no período matutino com tesoura de poda previamente desinfestadas em etanol $70 \%(\mathrm{v} / \mathrm{v})$. As miniestacas foram confeccionadas utilizando-se a parte apical das brotações, sendo confeccionadas com dimensões entre 4 e $5 \mathrm{~cm}$, contendo dois pares de folhas, as quais foram cortadas à metade, visando reduzir as perdas de água por transpiração. 


\section{Aplicação dos isolados bacterianos e estaqueamento}

Às miniestacas procedeu-se a aplicação das suspensões bacterianas, realizadas de três formas:

a) O primeiro método de dispensa utilizado foi adaptado do método de Kijima (KIJIMA, 1995), que se constituiu na imersão da base das miniestacas por um período de aproximadamente uma hora em suspensão bacteriana.

b) $\mathrm{O}$ segundo método utilizado consistiu na pulverização da suspensão bacteriana sobre o filoplano das miniestacas, sendo a pulverização foliar realizada com $5 \mathrm{~mL}$ da suspensão.

c) O terceiro método consistiu na dispensa dos isolados utilizando os dois métodos em conjunto.

Após a aplicação das suspensões de isolados bacterianos, as miniestacas foram estaqueadas $(2 \mathrm{~cm}$ de profundidade) em tubetes de $110 \mathrm{~cm}^{3}$ contendo substrato Macplant. Os tubetes e bandejas utilizados foram previamente lavados com detergente neutro e desinfestados em água quente a $83{ }^{\circ} \mathrm{C}$ por 30 segundos (ALFENAS et al., 2009). Os tubetes foram depositados em bandejas plásticas e levados para casa de vegetação regulada com $80 \%$ de umidade relativa do ar, com manutenção da umidade via nebulização por sistema do tipo fog, temperatura máxima de $25^{\circ} \mathrm{C} \pm 2$ e temperatura mínima $15^{\circ} \mathrm{C} \pm 2$. As miniestacas permaneceram por 30 dias na casa de vegetação, sendo transferidas para casa de sombra (50\% de retenção solar) por 30 dias e posteriormente acondicionadas em área de pleno sol por 30 dias, em um total de 90 dias de ensaio.

\section{Efeito dos isolados bacterianos sobre o crescimento e enraizamento das miniestacas}

Avaliou-se o percentual de sobrevivência das miniestacas na saída da casa de vegetação (SCV), na saída da casa de sombra (SCS) e na saída da área de pleno sol (SPL), bem como o percentual de miniestacas enraizadas na saída da área de pleno sol (EPL).

A avaliação do percentual de sobrevivência e enraizamento foi realizada através da contagem direta do número de miniestacas vivas e de miniestacas enraizadas durante cada etapa. Como miniestacas vivas foram consideradas todas aquelas que apresentaram a manutenção da coloração verde, e como miniestacas enraizadas consideraram-se todas aquelas que apresentaram, pelo menos, uma raiz visível.

\section{Delineamento experimental e análise estatística dos dados}

$\mathrm{O}$ experimento foi conduzido no delineamento de blocos casualizado, em arranjo fatorial (4 x 4x 3), sendo os fatores constituídos por quatro períodos de coleta de brotações, quatro isolados bacterianos e três métodos de dispensa dos isolados, com quatro blocos, utilizando-se quatro miniestacas por tratamento no bloco. A testemunha consistiu de miniestacas que não foram tratadas com os isolados bacterianos.

As médias obtidas foram analisados no software SAEG 9.1, procedendo-se a ANOVA e, quando pertinente, o teste de Tukey.

\section{RESULTADOS E DISCUSSÃO}

A análise de variância apresentou interação significativa entre o período de coleta das brotações e o isolado bacteriano utilizado para sobrevivência de miniestacas nas casas de vegetação (SCV), sombra (SCS) e área de pleno sol (SPL) e enraizamento na área de pleno sol (EPL). A interação do período de coleta das brotações com a forma de aplicação do isolado bacteriano foi significativa para SCV e SPL. A interação entre isolado bacteriano com a forma de aplicação foi significativa apenas para SCS, e a interação tripla não foi significativa para nenhuma das avaliações (Tabela 1).

Tabela 1. Análise de variância da sobrevivência de miniestacas avaliadas na saída da casa de vegetação (SCV), saída da casa de sombra (SCS) e na saída da área de pleno sol (SPL), com o percentual de enraizamento de miniestacas na saída da área de pleno sol (EPL).

Table 1. ANOVA of survival of mini-cuttings in the end of the green house phase (SCV), survival of mini-cuttings in the end of the shadow house (SCS), survival of mini-cutting in the end of the sun house (SPL) and percentage of rooting of min-cuttings in the end of the full sun area (EPL).

\begin{tabular}{|c|c|c|c|c|c|}
\hline \multirow[b]{2}{*}{ FV } & \multirow[b]{2}{*}{ GL } & \multicolumn{4}{|c|}{ Quadrado médio } \\
\hline & & SCV & SCS & SPL $^{(1)}$ & $\mathbf{E P L}^{(\mathbf{1})}$ \\
\hline Coleta $(\mathrm{Col})$ & 3 & $1,3328 *$ & $4,8697 *$ & $0,4498 *$ & $0,4080 *$ \\
\hline Isolado (Iso) & 4 & $0,0680^{\mathrm{ns}}$ & $0,0505^{\mathrm{ns}}$ & $0,2258 *$ & $0,1374 *$ \\
\hline Aplicação (Apli) & 2 & $0,5486^{*}$ & $0,3664 *$ & $0,1796^{\mathrm{ns}}$ & $0,0183^{\mathrm{ns}}$ \\
\hline Col x Iso & 12 & $0,0957 *$ & $0,1348 *$ & $0,1673 *$ & $0,1369 *$ \\
\hline Col x Apli & 6 & $0,2021 *$ & $0,0379^{\mathrm{ns}}$ & $0,1817 *$ & $0,0450^{\mathrm{ns}}$ \\
\hline Iso x Apli & 8 & $0,0307^{\mathrm{ns}}$ & $0,1050 *$ & $0,1355^{\mathrm{ns}}$ & $0,1041^{\mathrm{ns}}$ \\
\hline Col x Iso x Apli & 24 & $0,0570^{\mathrm{ns}}$ & $0,0833^{\mathrm{ns}}$ & $0,1396^{\mathrm{ns}}$ & $0,0778^{\mathrm{ns}}$ \\
\hline Bloco & 3 & $0,0266^{\mathrm{ns}}$ & $0,0391^{\mathrm{ns}}$ & $0,0665^{\mathrm{ns}}$ & $0,0709^{\mathrm{ns}}$ \\
\hline Resíduo & 177 & 0,0324 & 0,0483 & 0,0722 & 0,0538 \\
\hline
\end{tabular}

FLORESTA, Curitiba, PR, v. 46, n. 3, p. 387 - 395, jul. / set. 2016

Spassin, A. C. et al.

ISSN eletrônico 1982-4688

DOI: $10.5380 /$ rf.v46i3.38586 
Para a interação entre período de coleta das brotações e isolado bacteriano, não houve diferença estatística na SCV entre os isolados no primeiro e segundo períodos de coleta de brotações. No terceiro período, o isolado UBK12 e a testemunha não diferiram entre si e tiveram maior sobrevivência de miniestacas que os outros isolados bacterianos. No quarto período de coleta, os isolados RFE05 e RFE32 tiveram maior sobrevivência de miniestacas que os demais tratamentos (Figura 1a).

As variações de respostas de um mesmo isolado bacteriano na SCV das miniestacas em duas coletas distintas podem estar relacionadas a fatores ambientais e à fisiologia do vegetal, podendo essas interações influenciar na colonização e sobrevivência das bactérias e, com isso, em sua ação sobre a planta (MAFIA et al., 2007).
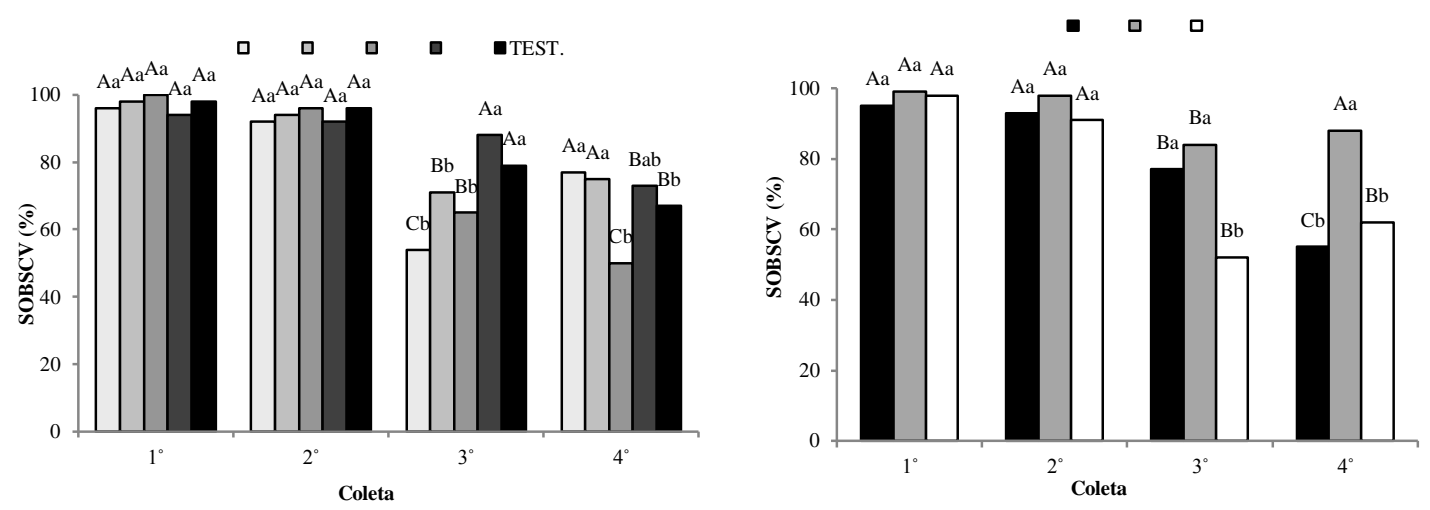

Figura 1. Sobrevivência de miniestacas de E. dunnii avaliada na saída da casa de vegetação (SCV). (a) interação entre período de coleta das brotações (Coleta) e isolado bacteriano. (b) interação entre período de coleta das brotações (Coleta) e forma de aplicação dos isolados ( $\mathrm{K}=$ método de Kijima; $\mathrm{F}=$ aplicação no filoplano; $\mathrm{K}+\mathrm{F}=$ uso combinado das duas formas de aplicação). Médias seguidas por uma mesma letra não diferem estatisticamente entre si pelo teste de Tukey a 5\% de probabilidade. Letras maiúsculas para um mesmo tratamento entre períodos de coleta; letras minúsculas dentro de um mesmo período de coleta.

Figure1. Survival of minicuttings of E. dunnii measures in the end of time of greenhouse (SCV). (a) interaction between period to harvesting of shoots (Coleta) and bacteria isolate. (b) interaction between period to harvesting of shoots (Coleta) and kind to delivery of isolate $(\mathrm{K}=$ Kijima method; $\mathrm{F}=$ phylloplane delivery; $\mathrm{K}+\mathrm{F}=$ both methods of delivery of bacteria). Means followed by the same letters do not differ significantly by the Tukey test to $5 \%$ of probability. Uppercase letters for the same treatment between sampling periods; lowercase letter within the same collection period.

As miniestacas de E. dunnii apresentaram valores de sobrevivência superiores a $90 \%$ na saída da casa de vegetação no primeiro e segundo períodos de coletas realizados. No terceiro e quarto período de coleta das brotações houve uma queda na sobrevivência em relação aos dois períodos anteriores, com valores inferiores a $80 \%$, exceto no quarto período para a aplicação via filoplano, sendo observadas diferenças entre os métodos de aplicação utilizados para essas duas últimas coletas (Figura 1b).

Os percentuais de sobrevivência na saída da casa de vegetação observados no presente trabalho assemelham-se ao encontrado por Souza Junior e Wendling (2003). Esses autores relatam 100\% de sobrevivência de miniestacas de E. dunnii na saída da casa de vegetação. Embora importante a avaliação da sobrevivência de miniestacas na saída da casa de vegetação, a eficiência final na produção de mudas depende das condições ambientais e de eventos adversos que podem ocorrer nas fases subsequentes do processo de enraizamento.

Pela análise de Tukey do desdobramento da interação entre período de coleta das brotações e forma de aplicação dos isolados bacterianos, observa-se que a SCV foi estatisticamente igual para todas as formas de aplicação dos isolados bacterianos no primeiro e segundo períodos de coleta de brotações. A aplicação via método de Kijima e via filoplano teve maior SCV que o uso combinado dos dois métodos no terceiro período de coleta de brotações. No quarto período de coleta, a SCV foi maior quando o método de aplicação utilizado foi via filoplano, diferindo significativamente da aplicação via método Kijima e pelo uso combinado dos dois métodos $(\mathrm{K}+\mathrm{F})$ (Figura 1b). Embora o método de Kijima seja recomendado para quando se pretende aplicar o agente promotor no interior dos tecidos, ele por vezes implica a redução do desenvolvimento - postula-se que pelo modo drástico inerente ao método, que implica a secção de tecidos (FERRAZ et al., 2008). Esses autores observaram que o método de Kijima também implicou a mortalidade de plantas em relação à aplicação via filoplano. A aplicação de bactérias no filoplano representa uma opção prática e menos onerosa de aplicação de agentes promotores. Carrer Filho et al. (2008) tiveram bons resultados aplicando rizobactérias pelo filoplano de plantas. 
Os resultados da interação entre período de coleta das brotações e isolado bacteriano para a SCS foi significativo. No primeiro, segundo e quarto períodos de coleta, os isolados não diferiram significativamente entre si e da testemunha. No terceiro período, o isolado RFE42 teve menor SCS que os demais tratamentos. Todos os tratamentos tiveram maior SCS nos dois primeiros períodos de coleta das brotações em relação aos dois últimos, exceto para o isolado RFE32, cuja redução de sobrevivência foi observada apenas na quarta coleta (Figura 2a).

Segundo Dias et al. (2012), a ausência do efeito das bactérias na sobrevivência das miniestacas nas fases iniciais de enraizamento e aclimatização pode ser explicado pelo fato de as mudas estarem utilizando suas próprias reservas internas para a sobrevivência e a formação do sistema radicular. Assim, não ocorre a disponibilização de fotoassimilados para o filoplano e/ou rizosfera, sendo eles necessários ao estabelecimento e desenvolvimento das colônias microbianas.
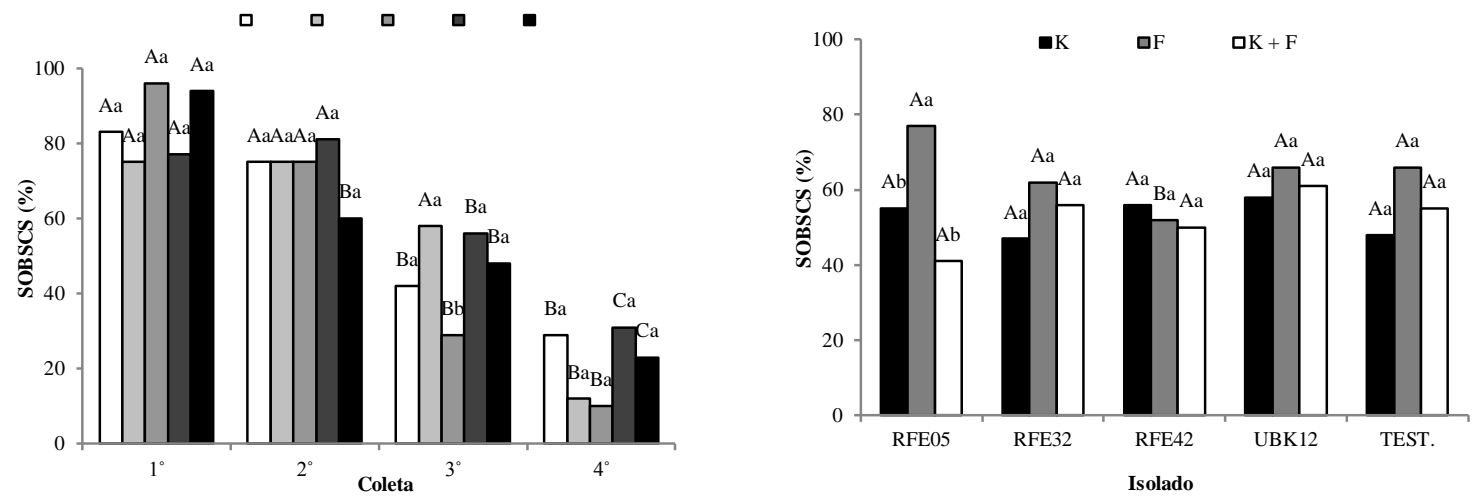

Figura 2. Sobrevivência de miniestacas de E. dunnii avaliada na saída da casa de sombra (SCS). (a) interação entre período de coleta das brotações (Coleta) e isolado bacteriano. Médias seguidas por uma mesma letra não diferem estatisticamente entre si pelo teste de Tukey a 5\% de probabilidade. Letras maiúsculas para um mesmo isolado entre diferentes períodos de coleta; letras minúsculas entre diferentes isolados dentro de um mesmo período de coleta. (b) interação entre isolado bacteriano (Isolado) e forma de aplicação dos isolados ( $\mathrm{K}=$ método de Kijima; $\mathrm{F}=$ aplicação no filoplano; $\mathrm{K}+\mathrm{F}=$ uso combinado das duas formas de aplicação). Médias seguidas por uma mesma letra não diferem estatisticamente entre si pelo teste de Tukey a 5\% de probabilidade de erro. Letras maiúsculas para um mesmo método de aplicação entre diferentes isolados utilizados; letras minúsculas entre os métodos de aplicação dentro do mesmo isolado utilizado.

Figure 2. Survival of minicuttings of E. dunnii measures in the end of time of shadow house (SCV). (a) interaction between period to harvesting of shoots (Coleta) and bacterial isolate. Means followed by the same letters do not differ significantly by the Tukey test to $5 \%$ of probability. Uppercase letters for the same isolated from different collection periods; lower case letters between different isolates within the same collection period. (b) interaction between bacterial isolate and kind to application of isolate ( $\mathrm{K}=$ Kijima method; $\mathrm{F}=$ phylloplane delivery; $\mathrm{K}+\mathrm{F}=$ both methods of delivery of bacteria). Means followed by the same letters do not differ significantly by the Tukey test to $5 \%$ of probability. Uppercase letters for the same method of application used between different isolates; lowercase letters between the application methods used within the same isolated.

Os valores de sobrevivência inferiores a $60 \%$ na saída da casa de sombra parecem ser normais para E. dunnii (ROSA et al., 2009). A redução no percentual de sobrevivência entre as fases de casa de vegetação e casa de sombra são tidas como normais para espécies subtropicais de Eucalyptus (BRONDANI et al., 2014). Relata-se que, por vezes, a sobrevivência ao fim da casa de vegetação pode reduzir a níveis de perda total do material (BRONDANI et al., 2010a; b). Uma possível explicação para esse efeito é a não formação de raízes adventícias pelas miniestacas, o que inviabiliza a continuidade do desenvolvimento do material.

Do desdobramento da interação entre metodologia de aplicação e isolados bacterianos, observou-se que o isolado RFE05 teve a maior SCS com a aplicação via filoplano, alcançando valores próximos a $80 \%$. Para os demais isolados bacterianos e a testemunha, não houve efeito entre o método de aplicação utilizado e SCS (Figura 2b).

Entre os isolados bacterianos, constataram-se diferenças significativas em relação ao método de aplicação utilizado. Na aplicação dos isolados bacterianos via método de Kijima e no uso combinado com aplicação pelo filoplano, os tratamentos não diferiram entre si. Contudo, as miniestacas que foram tratadas com o

FLORESTA, Curitiba, PR, v. 46, n. 3, p. 387 - 395, jul. / set. 2016.

Spassin, A. C. et al.

ISSN eletrônico 1982-4688

DOI: $10.5380 /$ rf.v46i3.38586 
isolado RFE42 via filoplano apresentaram percentuais inferiores de sobrevivência quando comparadas com a aplicação do mesmo método nos demais isolados e na testemunha (Figura 2b).

As diferenças observadas entre os métodos de aplicação e os isolados podem estar relacionadas à maior ou menor aptidão que uma determinada bactéria apresenta em colonizar uma determinada região da planta. Garcia (2008), ao avaliar o efeito de uma rizobactéria estirpe de Bacillus cereus no controle da ferrugem do feijoeiro e produção de grãos, observou que, ao aplicar a rizobactéria por meio de microbiolização de sementes, obtinha melhores resultados tanto para o biocontrole como para a produção de grãos, em relação a quando se aplicava essa mesma estirpe de bactéria no filoplano de plantas de feijão. Diferentemente, Carrer Filho et al. (2008) não observaram efeito significativo ao dispensarem no filoplano ou no rizoplano uma estirpe de Noccardioides thermolinacnus, de modo que é possível que a maior aptidão em colonizar um ou outro hábitat ou os dois dependa da espécie microbiana estudada. Dessa forma, saber se existe essa interação é importante, pois pode influenciar no sucesso ou no insucesso do uso do agente promotor. No presente trabalho, pode-se perceber que em relação à SCS a forma de aplicação não influenciou os resultados.

Em relação à sobrevivência das miniestacas na saída da área de pleno sol (SPL), observou-se, pela interação entre período de coleta de brotações e isolado bacteriano, que no primeiro e terceiro períodos de coleta não houve diferença significativa entre os isolados. No segundo período de coleta, a testemunha teve a maior SPL. No quarto período de coleta de brotações, os isolados RFE05 e UBK12 foram estatisticamente superiores aos demais isolados bacterianos e à testemunha (Figura 3a).
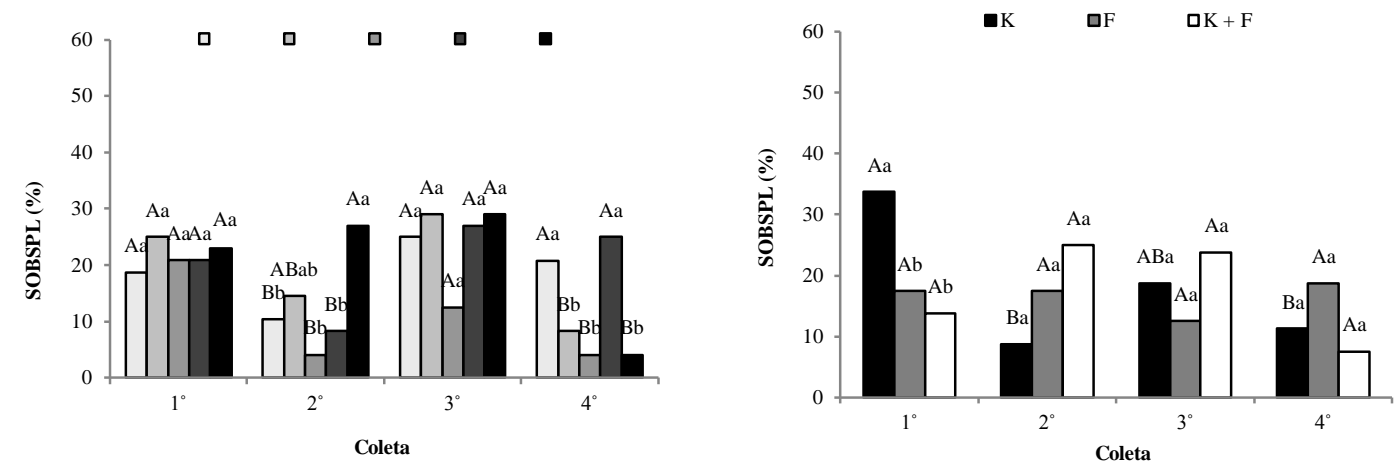

Figura 3. Sobrevivência de miniestacas de E. dunnii avaliada na saída da área de pleno sol (SPL). (a) interação entre período de coleta das brotações (Coleta) e isolado bacteriano. (b) interação entre período de coleta das brotações (Coleta) e forma de aplicação dos isolados ( $\mathrm{K}=$ método de Kijima; $\mathrm{F}=$ aplicação no filoplano; $\mathrm{K}+\mathrm{F}=$ uso combinado das duas formas de aplicação). Médias seguidas por uma mesma letra não diferem estatisticamente entre si pelo teste de Tukey a 5\% de probabilidade. Letras maiúsculas para um mesmo tratamento entre períodos de coleta; letras minúsculas entre diferentes tratamentos dentro de um mesmo período de coleta.

Figure 3. Survival of minicuttings of E. dunnii measures in the end of time of acclimation sun area (SPL). (a) interaction between period to harvesting of shoots (Coleta) and bacterial isolate. (b) interaction between priod to harvesting shoots and (Coleta) and kind to application of isolate ( $\mathrm{K}=$ kijima method; $\mathrm{F}=$ phylloplane delivery; $\mathrm{K}+\mathrm{F}=$ both methods of delivery of bacteria). Means followed by the same letters do not differ significantly by the Tukey test to $5 \%$ of probability. Uppercase letters for the same treatment between sampling periods; lowercase letter between different treatments within the same collection period.

A variação encontrada nos resultados de SPL pode ser explicada por diversos fatores que influenciam na interação planta-bactéria e que podem alterar o efeito do isolado sobre a planta. Um desses fatores, por exemplo, pode ser a dificuldade dos isolados de colonizar o ambiente (BUDDRUS-SCHIEMANN et al., 2010). Os mesmos autores postulam que rizobactérias com baixa capacidade de colonizar a rizosfera normalmente não são boas promotoras de crescimento vegetal (BUDDRUS-SCHIEMANN et al., 2010).

A associação dos microrganismos com o tecido vegetal é essencial para que haja interação benéfica entre eles. As condições ambientais são um dos principais fatores que interferem no estabelecimento dos microrganismos incorporados na planta. As oscilações ambientais podem afetar negativamente a capacidade de colonização bacteriana, assim como a espécie de planta que está sedo colonizada. Assim, uma planta que exsuda mais fotoassimilados pode suportar uma maior população bacteriana associada (MERCIER; LINDOW, 2000). A 
própria arquitetura do órgão a ser colonizado (VACHERON et al., 2013) influencia a capacidade de estabelecimento do microrganismo com o vegetal.

O desdobramento da interação entre período de coleta das brotações e método de aplicação dos isolados bacterianos demonstra que no primeiro período o método de Kijima propiciou o maior SPL. Nos demais períodos de coleta não houve efeito entre os métodos de aplicação. O método de Kijima teve maior SPL no primeiro período de coleta de brotação, enquanto nos demais métodos a SPL não diferiu estatisticamente entre os períodos avaliados (Figura 3b).

Houve interação significativa entre o tratamento controle e o período de coleta de brotações no enraizamento de miniestacas avaliado na saída da área de pleno sol (EPL). No segundo e terceiro períodos de coleta, houve maior enraizamento que no primeiro e quarto períodos. Para os isolados RFE05, RFE42 e UBK12 não houve interação entre o período de coleta de brotações avaliadas. Para o isolado RFE32, o maior percentual de EPL foi no terceiro período. Para a testemunha, os maiores percentuais de enraizamento deram-se no segundo e terceiro períodos de coleta de brotações (Figura 4).

$\mathrm{Na}$ avaliação no primeiro período de coleta nenhum tratamento teve EPL estatisticamente diferente. O mesmo resultado foi observado no quarto período. No segundo período, o EPL foi maior para a testemunha em relação aos tratamentos RFE05 e RFE42, e estatisticamente igual a RFE32 e UBK12. No terceiro período de coleta, a testemunha teve um enraizamento maior que o isolado UBK12 e estatisticamente igual aos demais isolados (Figura 4).

É importante ressaltar que os percentuais de SPL (Figura 3a e b) foram superiores aos de miniestacas enraizadas (Figura 4). Esse fato é importante, pois a sobrevivência na área de pleno sol não implica enraizamento, de modo que as miniestacas podem continuar vivas mesmo sem terem produzido raízes. Benin et al. (2013) observaram variações de $17 \%$ a $14 \%$ entre a SPL e o EPL, respectivamente, para miniestacas de $E$. benthamii, uma espécie muito relacionada a $E$. dunnii. Isso pode ocorrer porque mesmo após um período longo de mais de 100 dias as miniestacas podem sobreviver de nutrientes armazenados em seus tecidos, adquiridos enquanto eram brotações das minicepas. Contudo essa muda, se expedida para o plantio, não irá se desenvolver, levando a falhas no plantio.

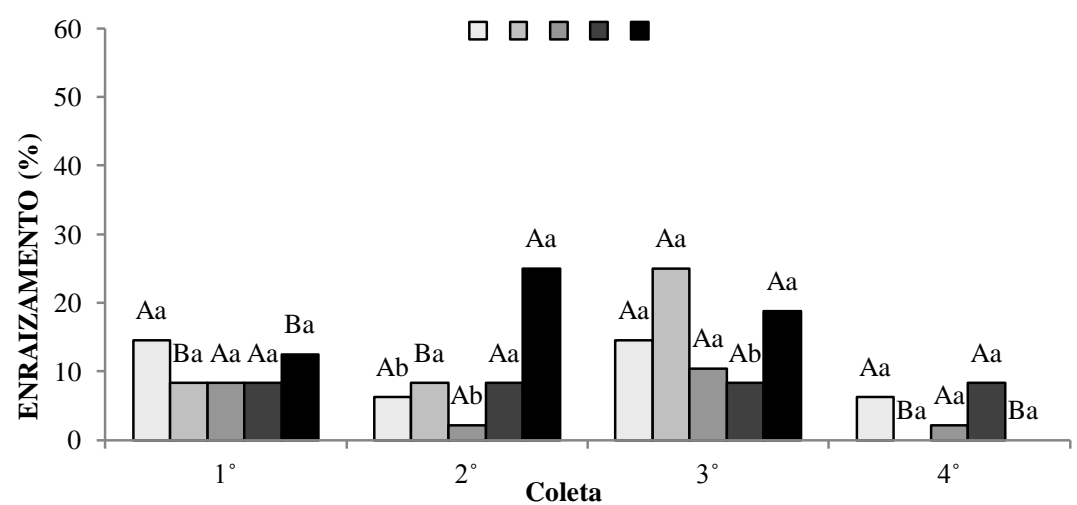

Figura 4. Enraizamento das miniestacas de E. dunnii avaliado na saída da área de pleno sol (EPL), em função da interação entre o período coleta das brotações e isolado bacteriano. Médias seguidas por uma mesma letra maiúscula para o mesmo isolado entre diferentes coletas e letras minúsculas entre os isolados dentro de uma mesma coleta não diferem significativamente pelo teste de Tukey a 5\% de probabilidade de erro.

Figure 4. Rooting of minicuttings of E. dunnii measures in the end of time of acclimation sun area (EPL), in function of interaction between period to harvesting of shoots and bacterial isolate. Means followed by the same letters do not differ significantly by the Tukey test to $5 \%$ of probability. Uppercase letters for the same treatment between sampling periods; lowercase letter within the same collection period.

No presente estudo não houve um isolado bacteriano que apresentasse resultado significativo no EPL. Existem vários relatos de microrganismo provendo o enraizamento de miniestacas de eucalipto (MAFIA et al., 2007; MAFIA et al., 2009; RAASCH et al., 2013), porém há casos em que são observados efeitos deletérios ao vegetal (SANTOS et al., 2008; SCHLINDWEIN et al., 2008).

Em relação ao enraizamento, a maioria dos trabalhos envolvendo microrganismos trabalharam com material não recalcitrante ou de protocolos de enraizamento já estabelecidos (TEIXEIRA et al., 2007; MAFIA et al., 2007; MAFIA et al., 2009), diferentemente do que é relatado para $E$. dunnii, uma espécie sabidamente recalcitrante ao enraizamento adventício e ainda em fase de implantação em plantios comerciais.

FLORESTA, Curitiba, PR, v. 46, n. 3, p. 387 - 395, jul. / set. 2016

Spassin, A. C. et al.

ISSN eletrônico 1982-4688

DOI: $10.5380 /$ rf.v46i3.38586 
Em relação ao efeito de promoção de crescimento, sabe-se que quando o agente promotor se encontra em situação de estresse ele pode produzir metabólitos que são inibitórios ao desenvolvimento vegetal. No presente trabalho não se relata nenhum efeito estressante para as bactérias, porém não é possível afirmar que alterações ambientais no filoplano e/ou rizosfera tenham tido esse efeito.

As diferenças observadas no enraizamento das miniestacas durante os quatro períodos de coleta de brotações podem estar relacionadas a diversos fatores. Segundo Figueiredo et al. (2011), podem ocorrer grandes variações na capacidade rizogênica entre espécies de Eucalyptus e entre indivíduos da mesma espécie. Essas variações são atribuídas principalmente a diferentes condições que as miniestacas podem apresentar depois de sua coleta, como incidência de doenças, mudas com sistema radicular malformado e queda no potencial de enraizamento das miniestacas com o envelhecimento ontogênico das plantas matrizes.

Em termos gerais, os percentuais de enraizamento registrados para as miniestacas aos 90 dias de idade foram inferiores a $30 \%$ nas quatro coletas realizadas. Embora seja um resultado muito baixo para o enraizamento, os resultados encontrados aqui são semelhantes e até mesmo superiores ao encontrados por alguns autores (ROSA et al., 2009).

O presente trabalho é o primeiro relato do uso de rizobactérias e bactérias residentes de filoplano para a promoção de crescimento de miniestacas de E. dunnii.

\section{CONCLUSÕES}

- A sobrevivência e o enraizamento das miniestacas variaram conforme a coleta, o isolado e método de aplicação utilizado.

- Dependendo do período da coleta, os isolados bacterianos apresentaram efeito ora benéfico, ora deletério na sobrevivência das miniestacas.

- Não foi observado efeito benéfico na indução do enraizamento das miniestacas de E. dunnii pelos isolados bacterianos.

- Não houve efeito pronunciado no método de aplicação utilizado devido à ausência do efeito promotor dos isolados bacterianos testados.

\section{AGRADECIMENTOS} estudos.

À Coordenação de Aperfeiçoamento de Pessoal de Nível Superior (CAPES), pela concessão da bolsa de

\section{REFERÊNCIAS}

ALFENAS, A. C.; ZAUZA, E. A. V.; MAFIA, R. G.; ASSIS, T. F. Clonagem e doenças do eucalipto. Viçosa: Editora UFV, 2009. 500 p.

ASSIS, T. F.; MAFIA, R. G. Hibridação e clonagem. In: BORÉM, A. (Ed.). Biotecnologia Florestal. Visconde do Rio Branco, 2007. p. 93-121.

BENIN, C. C.; PERES, F. S. B.; GARCIA, F. A. O. Enraizamento de miniestacas apicais, intermediárias e basais em clones de Eucalyptus benthamii. Revista Floresta, Curitiba, v. 43, n. 3, p. 421-428, 2013.

BEZERRA, G. A.; SOBRINHO, N. A.; SILVA, W. A.; NASCIMENTO, I. O.; SILVA, G. B.; FILIPPI, M. C. C. Avaliação do efeito do silicato de cálcio e magnésio na produtividade do arroz (Oryza sativa L.) em rotação de cultura com soja (Glycine max (L.) Merrill) em sistema de plantio direto. Revista Agroecossistemas, Belém, v. 5, n. 1, p. 25-31, 2013.

BRONDANI, G. E.; WENDLING, I.; GROSSI, F.; DUTRA, L. F.; ARAÚJO, M. A. Miniestaquia de Eucalyptus benthamii x Eucalyptus dunnii: (II) sobrevivência e enraizamento de miniestacas em função das coletas e estações do ano. Ciência Florestal, Santa Maria, v. 20, n. 3, p. 453-465, 2010a.

BRONDANI, G. E.; GROSSI, F.; WENDLING, I.; DUTRA, L. F.; ARAÚJO, M. A. Aplicação de IBA para o enraizamento de miniestacas de Eucalyptus benthamii Maiden \& Cambage x Eucalyptus dunnii Maiden. Acta Scientiarium, Agronomy, Maringá, v. 32, n. 4, p. 667-674, 2010 b.

BRONDANI, G. E.; BACCARIN, F. J. B.; BERGONCI, T.; GONÇALVES, A. N.; ALMEIDA, M. Miniestaquia de Eucalyptus benthamii: efeito do genótipo, AIB, zinco, boro e coletas de brotações. CERNE, Lavras, v. 20, n. 1, p. 147-156, 2014. 
BUDDRUS-SCHIEMANN, K.; SCHMID, M.; SCHREINER, K.; WELZL, G.; HARTMANN, A. Root colonization by Pseudomonas sp. DSMZ 13134 and impact on the indigenous rhizosphere bacterial community of barley. Microbial Ecology, New York, v. 60, n. 2, p. 381-383, 2010.

CARRER FILHO, R.; ROMEIRO, R. S.; GARCIA, F. A. O. Biocontrole de doenças de parte aérea do tomateiro por Nocardioides thermolilacinus. Tropical Pant Pathology, Brasília, v. 33, p. 457-460, 2008.

DIAS, P. C.; PEREIRA, M. S. F.; MEGUMIKASUYA, M. C.; PAIVA, H. N.; OLIVEIRA, L. S.; XAVIER, A. Micorriza arbuscular e rizóbios no enraizamento e nutrição de mudas de angico-vermelho. Revista Árvore, Viçosa, v. 36, n. 6, p. 1027-1037, 2012.

FERRAZ, H. G. M.; ROMEIRO, R. S.; GARCIA, F. A. O.; SOUZA, A. N. Biocontrole da mancha-alvo do tomateiro por Bacillus cereus em função do modo de dispensa na planta. Revista Trópica - Ciências Agrárias e Biológicas, São Luís, v. 2, p. 33-37, 2008.

FIGUEIREDO, F. A. M. M. A.; CARNEIRO, J. G. A.; PENCHEL, R. M.; BARROSO, D. G.; DAHER, R. F. Efeito das variações biométricas de mudas clonais de eucalipto sobre o crescimento no campo. Revista Árvore, Viçosa, v. 35, n. 1, p. 1-11, 2011.

GARCIA, F. A. O.; ROMEIRO, R. S. Biocontrole da mancha-angular do feijoeiro por antagonistas bacterianos. Pesquisa Agropecuária Brasileira, Brasília, v. 46, p. 1603-1608, 2011.

HIGA, R. C. V.; HIGA, A. R.; TREVISAN, R.; SOUZA, M. V. R. Resistência e resiliência a geadas em Eucalyptus dunnii Maiden plantados em campo do tenente, PR. Boletim de Pesquisa Florestal, Colombo, n. 40, p. 67-76, 2000.

KIJIMA, T.; YONAI, S.; OOHASHI, K.; AMAGAI, M. Process for biologically preventing dicotyledoneous plant diseases using symbiotic bacteria. USA Patent n. 5.401.655. 1995.

MAFIA, R. G.; ALFENAS, A. C.; MAFFIA, L. A.; FERREIRA, E. M.; BINOTI, D. H. B.; SIQUEIRA, L. Microbiolização e interação entre rizobactérias promotoras do crescimento e clones de eucalipto. Revista Árvore, Viçosa, v. 33, n. 5, p. 789-797, 2009.

MERCIER, J.; LINDOW, S. E. Role of leaf surface sugars in colonization of plants by bacterial epiphytes. Applied and Environmental Microbiology, Washington, DC, v. 66, n. 01, p. 369-374, 2000.

PERALTA, K. D.; ARAYA, T.; VALENZUELA, S.; SOSSA, K.; MARTÍNEZ, M.; PEÑA-CORTÉS, H.; SANFUENTES, E. Production of phytohormones, siderophores and population fluctuation of two rootpromoting rhizobacteria in Eucalyptus globulus cuttings. World Journal of Microbiology and Biotecnology, New York, v. 28, p. 2003-2014, 2012.

RAASCH, L. D.; BONALDO, S. M.; OLIVEIRA, A. A. F. Bacillus subtilis: enraizamento e crescimento de miniestacas de eucalipto em Sinop, norte de Mato Grosso, Brasil. Bioscience Journal, Uberlândia, v. 29, n. 1, p. 1446-1457, 2013.

ROSA, L. S.; WENDLING, F. G.; REISSMANN, C. B. Efeito da dose de nitrogênio e de formulações de substratos na miniestaquia de Eucalyptus dunnii Maiden. Revista Árvore, Viçosa, v. 33, n. 6, p. 1025-1035, 2009.

SANTOS, M. M.; CARVAlHO, F. C. Q.; FRANÇA, F. S.; DOURADO, D. L.; GUIMARÃES, L.; KARASAWA, M.; PAZ, C. D. Características fenotípicas de rizobactérias obtidas de cucurbitáceas com potencial de promover crescimento em plantas de abóbora. Horticultura Brasileira, Brasília, v. 26, n. 2, p. $1539-1543,2008$.

SCHLINDWEIN, G.; VARGAS, L. K.; LISBOA, B. B.; AZAMBUJA, A. C.; GRANADA, C. E.; GABIATTI, N. C.; PRATES, F.; STUMPF, R. Influência da inoculação de rizóbios sobre a germinação e o vigor de plântulas de alface. Ciência Rural, Santa Maria, v. 38, n. 3, p. 658-664, 2008.

SOUZA JUNIOR, L.; WENDLING, I. Propagação vegetativa de Eucalyptus dunnii via miniestaquia de material juvenil. Boletim de Pesquisa Florestal, Colombo, n. 46, p. 21-30, 2003.

TEIXEIRA, D. A.; ALFENAS, A. C.; MAFIA, R. G.; FERREIRA, E. M.; SIQUEIRA, L.; MAFFIA, L. A.; MOUNTEER, A. H. Rhizobacterial promotion of eucalypt rooting and growth. Brazilian Journal of Microbiology, São Paulo, v. 38, n. 1, p. 118-123, 2007.

VACHERON, J.; DESBROSSES, G.; BOUFFAUD, M. L.; TOURAINE，B.; MOËNNE-LOCCOZ，Y.; MULLER, D.; LEGENDRE, L.; WISNIEWSKI-DYÉ, F.; PRIGENT-COMBARET, C. Plant growth-promoting rhizobacteria and root system functioning. Frontiers in Plant Science, Tucson, v. 4, n. 1. p. 1-19, 2013.

FLORESTA, Curitiba, PR, v. 46, n. 3, p. 387 - 395, jul. / set. 2016

Spassin, A. C. et al.

ISSN eletrônico 1982-4688

DOI: $10.5380 /$ rf.v46i3.38586 